\title{
Nóbelsverðlaun í læknisfræði 2019 - Súrefnisskynjun frumunnar
}

Pað var stórt skref fyrir próun lífs á jörðinni pegar frumur fóru að nota súrefni til að knýja áfram efnaverksmiðju sína til orkuframleiðslu. Pessi nýsköpun varð til pess að líf á jörðunni tók stakkaskiptum, heilkjörnungar urðu til og síðar fjölfruma lífverur. Mikilvægi súrefnis hefur verið pekkt öldum saman en pað er ekki fyrr en nýlega sem vísindamenn áttuðu sig á pví hvernig frumur lífvera laga sig að breytingum á súrefnismagni. Nóbelsverðlaunin í læknisfræði árið 2019 tengjast pessu en pau hljóta prír vísindamenn fyrir grundvallaruppgötvanir á pví hvernig fruman bregst við súrefni og súrefnisskorti. Vísindamennirnir eru William G. Kaelin Jr. við Harvard-háskóla, Sir Peter J. Ratcliffe við Francis Crick-stofnunina í London og Gregg L. Semenza við Johns Hopkins-háskóla.

Pegar súrefni varð lykilsameind í orkuframleiðslu lífvera gat margfalt meiri orka myndast við niðurbrot fæðusameinda og lífverur gátu farið að framkvæma flóknari hluti; búa til flóknar sameindir, senda skilaboð og ýmislegt annað. Á sama tíma varð einnig nauðsynlegt að geta skynjað súrefnismagn pannig að lífveran gæti aðlagast mismiklu súrefni í umhverfinu.

Раð hefur verið lengi pekkt að svæði í nýrum skynja lágan súrefnisstyrk (eða blóðleysi) og kveikja á aukinni framleiðslu á erythropoietíni (EPÓ), hormóni sem eykur myndun rauðra blóðkorna. Rannsóknir Semenza og samstarfsmanna sýndu að umritunarpáttur í kjarna frumna stýrði með beinum hætti framleiðslu á EPÓ. Pessi umritunarpáttur, hypoxia-inducible factor-1 (HIF-1), reyndist vera lykilstýripáttur í nýrum á pessu mikilvæga hormóni, EPÓ. Framhaldsrannsóknir Semenza sýndu síðar að HIF-1 var stýrt með beinum hætti af súrefnisstyrk í umhverfi frumnanna. Parna var komin bein lífeðlisfræðileg stjórnun á myndun blóðrauða gegnum skynjun á súrefnisstyrk í lífverunni.

Næsti kafli í pessari áhugaverðu sögu snýr að rannsóknum á æxlisbæligeninu VHL (von Hippel Lindau) sem hafði verið einangrað í sjaldgæfu krabbameinsheilkenni sem tengdist myndun á æðaríkum illkynja æxlum. Pessi æðaríku æxli örvuðu HIF-1 umritunarpáttinn sem Semenza hafði rannsakað nokkrum árum áður. Ratcliffe og samstarfsmenn sýndu fram á VHL-próteinið stýrði með beinum hætti niðurbroti á HIF-1 og petta niðurbrot var einnig súrefnisháð í frumunni. Pannig hefur fruman pann hátt á að framleiða stöðugt HIF-1 umritunar- páttinn en brjóta hann niður á sama tíma og pannig koma í veg fyrir virkni hans. VHL-æxlisbæligenið stýrir beint pessu niðurbroti. Æxxli sem skortir petta prótein brjóta pví ekki niður HIF1 og pví fer fruman að haga sér eins og hún sé í súrefnissnauðu ástandi. Æxli af pessari gerð hvetja nýmyndun æða og efnaskipti æxlisins breytast eins og pað sé í súrefnissnauðu umhverfi. Rannsóknir benda til að fjölmörg æxli taki upp svipaða hegðum, en petta er rannsóknarsvið í dag sem er frjótt og snýr að efnaskiptum krabbameinsfrumna.

Síðast kaflinn í pessari áhugaverðu sögu um skynjun á súrefnisstyrk í frumum var skrifaður af rannsóknarhópum Ratcliffe og Kaelin. Peir birtu samtímis tímamótagreinar sem lýstu ensími sem hengdi hydroxýl (-OH) á HIF-1-umritunarpáttinn sem hefur leikið lykilhlutverk í pessari sögu. Ensímið, svokallaður prólýl-hdroxýlasi, var súrefnisháð og pví minnkaði virkni pess pegar súrefnisstyrkur lækkaði. Parna voru pví komin hinu beinu tengsl súrefnis og HIF-1. Við eðlilegan súrefnisstyrk var HIF-1 merkt til niðurbrots gegnum prólýlhydroxýlasa. VHL-próteinið stuðlar síðan að niðurbroti pess. Við súrefnisskort er HIF-1 hins vegar ekki brotið niður og getur pví sent skilaboð um súrefnisskort sem leiðir af sér aðlögun lífverunnar, meðal annars með myndun á EPÓ, nýmyndun æða og aðlögun efnaskipta að súrefnissnauðu ástandi.

Pessi grundvallarskilningur á súrefnisskynjun frumunnar hefur varpað ljósi á myndun blóðrauða, aðlögun lífvera að lágum súrefnisstyrk, til dæmis við háfjallaaðstæður, og hegðun krabbameinsfrumna. Petta er ljóslifandi dæmi um grundvallarrannsóknir sem varpa ljósi á mörg svið klínískrar læknisfræði og pví verðugt æðstu viðurkenningar í læknavísindum.

\section{Heimildir}

1. Semenza GL, Nejfelt MK, Chi SM, Antonarakis SE. Hypoxia-inducible nuclear factors bind to an enhancer element located $3^{\prime}$ to the human erythropoietin gene. Proc Natl Acad Sci USA 1991; 88: 5680-4.

2. Wang GL, Jiang BH, Rue EA, Semenza GL. Hypoxia-inducible factor 1 is a basic-helix-loop-helix-PAS heterodimer regulated by cellular O2 tension. Proc Natl Acad Sci USA 1995; 92: 5510-4.

3. Maxwell PH, Wiesener MS, Chang GW, Clifford SC, Vaux EC, Cockman $\mathrm{ME}$, et al. The tumour suppressor protein VHL targets hypoxia-inducible factors for oxygen-dependent proteolysis. Nature 1999; 399: 271-5.

4. Ivan M, Kondo K, Yang H, Kim W, Valiando J, Ohh M, et al. HIFa targeted for VHL-mediated destruction by proline hydroxylation: Implications for O2 sensing. Science 2001; 292: 464-8.

5. Jaakkola P, Mole DR, Tian YM, Wilson MI, Gielbert J, Gaskell SJ, et al. Targeting of HIF- $\alpha$ to the von Hippel-Lindau ubiquitylation complex by O2-regulated prolyl hydroxylation. Science 2001; 292: 468-72.

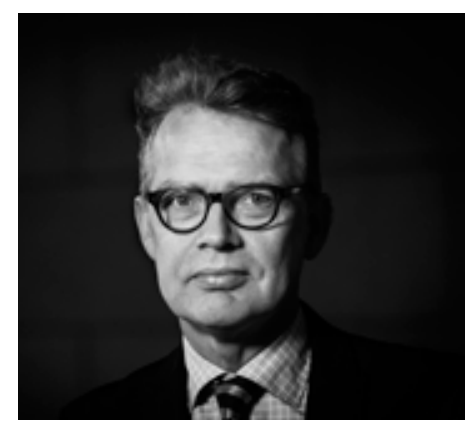

\section{Magnús K. Magnússon}

læknir

Læknadeild Háskóla Íslands og Íslenskri erfðagreiningu

magnuskm@hi.is

The Nobel Prize in Medicine 2019 - The cellular oxygen sensing mechanism

Magnús K. Magnússon MD, Professor, Faculty of Medicine, University of Iceland \& project leader, deCODE Genetics 